\title{
Tadeusz Szulc
}

\section{SPOSOBY WYNAGRADZANIA POBORCOW PODATKOWYCH W POLSCE OD SCHYEKU XIV DO XVIII WIEKU}

\section{ARTEN DER ENTLOHNUNG DER STEUEREINNEHMER IN POLEN VOM ENDE DES XIV. JH. BIS ZUM XVIII. JH.}

- Wstęp. - Systemy wynagradzania poborców. - Zasady pobierania spisnego.

- Ewolucja systemu wynagradzania poborców. - Wnioski.

- Einleitung. - Systeme der Entlohnung der Steuereinzieher. - Grundsätze der Einziehung von Quittungsgebühren. - Evolution des Systems der Entlohnung der Steuereinnehmer. - Schlußfolgerungen.

O wynagrodzeniu poborców od chwili wprowadzenia w 1374 r. stalego podatku nie pisano wiele. Literatura nie zajęla się również okresem późniejszym, to jest od polowy XV w., kiedy to wprowadzono praktyke częstszego uchwalania podatków nadzwyczajnych. Aby zilustrować stan wiedzy na ten iemat, przytoczmy kilka poglądów wyrażonych tak w starszych, jak i zupelnie niedawno publikowanych pracach z zakresu historii skarbowości.

Jan Rutkowski pisząc o wydatkach przeznaczonych na utrzymanie kancelarii Aleksandra Jagiellończyka, stwierdzał, iż „,do pewnego stopnia [obejmowaly one - T.S.] koszta administracji skarbowej; nie wyczerpuja jej jednak, należy tu bowiem doliczyć pieniądze dawane poborcom przynoszącym do skarbu pewne kwoty"'. W ten ogólnikowy spo-

1 J. Rutkowski, Skarbowość polska za Aleksandra Jagiellończyka, KH 1909, 
sób autor sygnalizowal zagadnienie wynagrodzenia poborców za ich pracę.

Z kolei Roman Rybarski w publikacji poświęconej skarbowości cza-sów Jana Kazimierza, Michała Korybuta i Jana III Sobieskiego pisał: „Poborcy otrzymują wynagrodzenie uchwalane przez sejmik, względnie biorą na swoja korzyść różne opłaty (kwitowe od kwitu, lub pewien procent od zebranej sumy)"'2. Jest to wypowiedź niejasna. Na jej bowiem podstawie można wnioskować, że jeżeli place poborców nie zostały ustalone przez sejmik, to poborcy wówczas brali różne opłaty... Wniosek powyższy jest niezgodny $\mathrm{z}$ wymową źródel, o czym będziemy pisać niżej.

Można by przypuszczać, że nowsza literatura historyczno-prawna przynosi szczególowsze ustalenia na interesujący nas temat. Henryk Karbownik przyjął, iz w XVI w. „Poborcy otrzymywali wynagrodzenie ze skarbu [państwa? - T.S.] [...] gdy rozliczyli się z zebranego podatku"3. Pogląd ten uściślił Władysław Pałucki stwierdzając, że od czasów

R. XXlli, s. 76. Skróty użyte w przypisach: AA - Acta Aleksandra, ed. F. P a p é e; Acta krak. - Akta sejmikowe wojewódzlwa krakowskiego; AGZ -- Akta Girodzkie i Ziemskic; AH - Acta Historica X, Lauda sejmików ziemii dobrzyńskiej, wyd. Fr. Kulczycki, Kraków 1887; AKH -- Archiwum Komisji Historycznej; AKP -. Archiwum Komisji Prawniczej; Arch. Sang. - Archiwum Ksiqżal Lubartowiczów San. guszków w Sławucie, wyd. Z. L. Radzimiński, B. Gorczak, II, 1284-1506, Lwów 1888; AT Acta Tomiciana; CUP -.. Codex Diplomaticus Poloniae; CE XV - Codex Epistolaris saeculi XV; CIP - Corpus luris Polonici, EHGP - Encyklopedia historii gospodarczej Polski, HPPP - Historia państwa i prawa Polski; IMT - Iura Masoviue Terrestria, ed. J. Saw icki; IP - I I s Polonicum, ed. J. W. Bandtki e; KDMp -Kodeks dyplomatyczny Matopolski; KDWp - Kodeks dyplomatyczny Wielkopolski; KH - "Kwartalnik Historyczny"; Lauda - Dzieje Ziemii Kujawskiej [...] Lauda $i$ instrukeye 1572-1674, ed. A. P a wi ńs k i, t. 2--5, Warszawa 1888; Mon. Iur. II Monumenta luris Matricularum Regni Poloniae codices saeculo XV conscripti, t. 1 , Liber distinctus numero 10 annorum 1447-1454, ed. A. Granicz y j, W. My sła wskij, Varsoviae 1914, nr 29; SiESr - Slownik laciny średniowiecznej w Polsce, red. S. Plezia; SPPP - Starodawne prawa polskiego pomniki; VL - Volumina Legum: ZNUJ - "Zeszyty Naukowe Uniwersytetu Jagiellon'skiego".

2 k. R y ba Iski, Skarb i pieniqdz za Jana Kazimierza, Michala Korybuta i Jana $H$, Warszawa 1939, s. 40.

${ }^{3} \mathrm{H}$. Ka r b ownik, Ciężary stanu duchownego w Polsce na rzecz państwa od roku 1381 do połowy XVII wieku, Lublin 1980, s. 112, z odesłaniem do IP, s. 254 (poprawnie, s. 284). We wskazanym miejscu znajdujemy jeden $\mathrm{z}$ artykułów nieszaw. skich z 1454 r. i jego edycji z 1496 r., ustanawiającego zakaz pobierania spiśnego (XXVI Spisne abrogatur; XXII De inscriptionibus alias napisne) $\mathrm{z}$ uwagą, że pobieranie wynagrodzenia zagrożono karą 3 grzywien. Badacz traktuje ów zakaz jako generalny, gdy tymczasem pobieranie spiśnego $w$ XV-XVI $w$. nie było ujmowane jednolicie, o czym będziemy pisać niżej. Z kolei w innym miejscu H. Karbownik pisząc o placeniu w 1381 r. poborcom poradlnego z okazji wypisania kwitu podat- 
Aleksandra ,,poborcy otrzymywali wynagrodzenie [...] od zebranej sumy"4. Ponicważ autor omawia organizację wladz skarbowych w okresie od XIV do XVIII w., należałoby sądzić, iż przedstawiony system opłacania egzaktorów byl obowiązujący aź do końca istnienia szlacheckiej Rzeczypospolitej. Czy tak było w istocie? Wreszcie Tadeusz Brzeczkowski, zajmujący się podatkami zwyczajnymi w XV stuleciu, pisząc o poradlnym $w$ dobrach kościelnych $\mathrm{w}$ roku 1381, przyjmuje: ,Wyznaczono nawet wynagrodzenie dla poborców podatków w majątkach klasztornych w wysokości 1 grosza z lanu od wsi" "5. Badacz ten następnie wskazuje, że dla XV w. ..Brak przekazów określających wynagrodzenie poborców podatków zwyczajnych, w przeciwieństwie do poborców podatków nadzwyczajnych".6. Jednak nie podaje żadnych informacji odnośnie do wynagradzania tych ostatnich.

Jak zatem wyglądało opłacanie osób wybierających świadczenia podatkowe na rzecz państwa w okresie od XIV do XVIII w.?

Møżliwości teoretyczne nagradzania działalności poborców podatknwych przedstawiają się następująco:

a) opłacani są oni przez panującego po odprowadzeniu zebranych należności do skarbu:

b) wynagrodzenie to może być również wyznaczone przez sejm lub sejmik.

$\mathrm{Tu}$ istnieje dwojala ewentualnośr: wynagrodzenie ustala się poprzez wyznaczenie nkreślonej kwoty (ryczalt), bądź przez wyrażenie płacy w stosunku procentowym do zebranej kwoty podatkowej (prowizja).

c) trzeci sposób sprowadza się do utrzymywania poborców z pieniędzy podatników.

Oczywiście możliwe, że albo równolegle, badź w następstwie chronologicznym. posłuģiwano się różnymi sposobami opłacania poborców. Tak też $\mathrm{w}$ źródłach znajdujemy potwierdzenie, iż egzaktorów wynagradzano z. pieniędzy podatników, jak i z zebranego podatku (tak w postaci z góry określonej kwoty, jak i procentowej).

kowego spiśnego, nie utożsamia jej z wynagrodzcniem dla poborów otrzymywanym z tytułu ich działalności (ibidem, s. 58-59).

EHCip II, s.v. skarbowość, s. 280 (autor W. Paluck - bez podania źródel, co wynika $z$ charakteru wydawnictwr.

sT. B rzeczkowski, Podatki zwyczajne w Polsce w XV wieku, "Acta Universitatis Nicolai Copernici" 1982, llistoria XVIII, s. 42. Nasuwa się tu watpliwośi, c7y bylo to wynagrodzenie z lanu czy od wsi? Autor odsyła do: J. Mat us ze wsk i, Immunitet ekonomiczny $w$ dobrach kościola w Poisce do roku 1381, Poznań 1935 , s. 130--131, gdzie podano, iż poborcy otrzymywali po 1 gr od wsi.

${ }^{6}$ B rzeczkowski, Podalki..., s. 52. Nie wyjaśnił, czy zasada wynagradzania poborców w dobrach klasztornych odnosila się także do poborców $w$ dobrach szlancheckich. 
Wskazówki o zasadzie wynagradzania osób wybierających podatki z domeny królewskiej wydają się być zawarte w pochodzących ze schylku panowania Kazinierza Wielkiego ${ }^{7}$ postanowieniach skierowanych do starostów:

Item de mandato dommi Regis statuimus, quod nullus Copitaneorum sive Procuratorlim videlicet in tora Cracoviensi, Sandomiriensi. Syradiensi, Lanciciensi, Cuyawiensi, Dobrinensi, Russice, ac alicrum tenutarum, alio modo non debet [sicl] vivere in tenutis regalibus, nisi tantumimodo de laboribus agrorum, alodiorum poenarum, molendinorum, lignorum decimarum, sub poena colli ac omnium bonorum, Et onnes provertus censuales et exactionum, integraliter domino Regi debet prcesentare od thesaurum [...] Item strtuimus firmiter, quod omnes proventus, qui proveniunt in toto regne Foloniaf, qui vulgariter nuncupantur Berne, omnes, sub poena colli ac omnium bonorum, Capifanei, Procuratores el ceteri officioles, debent reservari pro thesauto domini Regis ${ }^{\sharp}$.

W pierwszym ze statutów nakazywano starostom, wielkorządcom i zarządcom wszelkich dóbr królewskich w ziemiach krakowskiej, sandomierskiej, sieradzkiej. leczyckiej, kujawskiej. dobrzyńskiej i na Rusi, aby utrzymywali się z robocizny i dochodów w naturze, swiadczonych z łann k kmecynh i folwarków, jak też z wplywów pochodzących z mlynów, kar, dziesięciny drzcwnej. Natomiast wszelkie wpływy z tytułu czynszów pieniezżnych i podatków odprowadzane mialy być w calości do skarbu monarszego pod groźbą kary gardła i konfiskaty dóbr. Podobnie - według drugiego mandatu - podatek gruntowy z lanów chlop. skich zwany „berna” mial być przez starostów, wielkorządców i innych urzędnikow zachowany dia skarbu królewskiego?. W warunkach funkcjonowania gospodarki (zynszowej, gdy odezuwany był brak pieniądza. monarcha dążyl do zorewnienia napływu jego do skarbu, pozostawiając urzędnikom, dø ktorych nalèralo gromadzenie królewskich podatków, jako wynagrodzenie dochody z innych źródel. Pamiętamy przy tym, że ani

7 Z. Karzmarc yyk datuje wzmiankowane statuty (idac za: St. Kutrzeba, Wybór źródel do hislorii ustroju Polski, z. 1, Kraków 1922, s. 101) na lata 1368--1370. Monarchia Kcizimierza Wielkiego, t. 1, Crganizarja państwa, Poznań 1939, s. 125). Wskażmy, $i \dot{z}$ badacz ten nio zajmuje się zagadnieniem wynagrodzenia po. borców.

${ }^{8}$ SPIP I, s. 226.

9 lor. rit. Zdaniem Kaczmarczyka, władca pragnął w ten sposób zapobiec: naduzyciom i zapewnic : mbie większe dochody, jak tez podnieść znaczenie monety królewskiej. (Monarchia..., s. 126, 189). Wedlug J. Bardacha, celem mandatu byłn utryymanie kursu monety polskiej, tą droga zarazem usiłowano wprowidzić obowiq. zek przyjmowanid należności wyłącznie w tejże monecie, HPPP I, s. 469. Podobnie ujał J. Wyrozumski, podkreśldjąc iż panującemu zależało na ulworzeniu pie. niężnego skarbu państwowego. (Kazimierz Wielki, Wrocław 1982, s. 168). 
dla starostów, ani innych zarządców dóbr królewskich ${ }^{10}$ ściąganie podatków nie bylo ani jedynym, ani zasadniczym obowiązkiem.

Zmiany $w$ zakresie opłacania wzmiankowanych urzędników następują już po śmierci Kazimierza Wielkiego. Dowiadujemy się o tym z wydanych przez Ludwika Węgierskiego na rzecz instytutów kościelnych w 1381 r. przywilejów:

Voltimus eriam et ex innata benignitate decernimus pretextu recolligendo pecunie nullus Notariorum seu eciam ministerialium quitquid [sic] exigat seu requirat nisi unum grossum de quolibet villa ${ }^{11}$.

Poborcy przy ściagganiu od duchowieństwa poradlnego mogli domagać się opłaty w wysokości 1 gr od wsi, nie więcej. Nowy monarcha wprowadzal system, w ramach którego przerzucal koszty wynagrodzenia aparatu podatkowego na podatnika. Potwierdzenie stosowania tego sposobu oplacania urzędników w dobrach duchowieństwa, także w XV w., znajdujemy w uchwale synodu piotrkowskiego z 24.10.1464 r. Powołując się na nią, Piotr Pniewski, administrator archidiecezji gnieźnicńskiej, wzywal duchowieństwo dekanatu zbarskiego do zlożenia subsidium charitativum, inførmując zarazem:

Volumus insuper quatenus singuli collectores pro singulis quittanciis et laboribus medio grosso sint contenti².

Zezwalano poborcom na pobranie opłaty za wystawiane podatnikom kwity, poświadczające zaplacenie kontrybucji i za wykonaną pracę. Dla

${ }^{10} \mathrm{~K}$ a c zmarczyk wskazuje, iż w dokumencie $\mathrm{z} 30.05 .1365$ r. wymieniony został collector regalium exactionum. Zdaniem badacza, byl on specjalnym urzędnikiem wielkorządry, zbierajạcym królewskie daniny, które wielkorzadca odsyłał panujacemu na analogicznych zasadach jak starostowie. (Monarchia..., s. 190, z odesłaniem KDMp I, 277). Urzędnik ów wymieniony jest wśród świadków dokonywanej przez opata klasztoru cystersów w Andrzejowie, Gerarda, czynności prawnej. Poza wymienioną godnością świadka, nie wiemy nic, na czym polegała jego funkrja.

11 CDP 3, nr 164. Na zagadnienie wynagrodzenia poborców uwagę zwrócił $\mathrm{M}$ a. fuszewski, (Inmunitet..., s. 130-131), za nim ida: M. Zgórniak, (Relikty średniowiecznych powinnosci skarbowych na wsi malopolskiej XVI-XVIII wieku, Warszawa 1959, s. 67); B r zeczkowski, (Podatki.., s. 42). Spiśne wybierano równiez $w$ dobrach ziemskich świerkich. Pośrednio mówi o tym generalna klauzula przywileju piotrkowskiego z 1388 r., adresowand do poborców, zakazująca pobierania spiśnego przy okazji poboru poradlnego; zob. przyp. 16. Można domniemywac, że oplacrnie poborców spiśnym zwiąane było z wprowadzeniem w 1374 r. stałego dwugroszowego poradlnego.

${ }^{12} \mathrm{CE}$ XV, III, nr 101; we wcześniejszyın, bo z 24.10.1456 r., akcie Tomasz Strzepiniski biskup krakowski, rozpisując kontrybucję wśród kleru, polecał In signum solutionis quitantiam ab eisdem dominis collectoribus soluto ab ea uno grosso recepturi, $\mathrm{CE} \mathrm{XV,} \mathrm{I/2,} \mathrm{nr} 167$. 
państwa istotne bylo zebranie uchwalonych sum. Podatnika interesowalo natomiast poświadczenie, że wywiązał się z nałożonego nań obowiązku. Oczekiwał więc pokwitowania, które służylo jako środek umożliwiający odparcie ewentualn€fo zarzutu niepłacenia powinności:

Qui vero terrigenarum pro prima vice pignorationis repercusserit, extunc vigore Jandi, in praesenti conventione ronclusi, ad praesentiam tui, si nos tunc in terra tenutae tude praesentes non fuerimus, citari procures, et adhibito tibi terrae ilius, quem facilius attingere poteris, castellano et judice, aut subjudice terrestris, eundem cap tives, et de castro exire non permittas, nisi fidei et honoris obligatione, out cautione finejussorio illum astringendo, data tamen perprius citato defensione justitiae, alirs expurgatione sua per quittancias aut regestra collectoris audita ${ }^{13}$.

Pokwitowanie, o którym byla mowa w zacytowanym fragmencie uniwersału poborowego sejmiku nowokorczyńskiego z 6.10 .1472 r., wyraźnie chroniło zatem przed groźbą ponownego poboru i egzekucją. Wypadki takie - o czym wiadomo z lustracji - zdarzaly się: oto mieszkańcy wsi Lipińskie skarżylj się lustratorom, iż wybrano od nich wszystkie podatki, nie wydawszy im kwitu. ,których się poborów znowu teraźniejszy p. poborca u nich upomina"14.

System opłacania poborców przez spiśne ${ }^{15}$ nie utrzymał się długo. W rokı 1388 Wladysław Jagiello w przywileju piotrkowskim, w części odnoszącej się do wybierania pokoszyckiego poradlnego, postanawial:

13 IP, s. 312.

14 Lustracje województwa rawskiego XVII wieku, wyd. Z. Kędzierska, Wrocław 1965 , s. 193.

15 Nazewnictwo używane do wyrażenia tej instytucji jest nijeliczne. Określenia łacińskie są ubogie: descriprionalium (1451 I. -.. VL I, f. 158, autorzy SłESr V, 2. 5 (39) joko date podaja błednie rok 1447; 1472 r. - TP, s. 312; 1506 r. -. Polskie statuty ziemskie [...] (Syntagmata), oprac. L. Eysiak, S. Roman, Wrocław 1958, s. 168, pkt 9); inscriptio (1454 r. -- IP. s, 284, pkt XXII). Na Mazowszu spotykamy termin descripcioncles seu quadrantes (1448 r. -- IMT I, nr 95). W źródłach napotykamy terminologie lacińsko-polska: inscripcionales alias napysne $(1440 \mathrm{r}$ - KDWp $\mathrm{V}$, nr 659); notae seu spisne (1465 r. - SPPP 3, s. 111, c. 389). Polskie nazewnictwo stanowir rózne odmiany slowa "napisne" $(1388,1410,1425,1$ 1455, 1501, 1503, $1518 \mathrm{r}$. - M. Handelsman, Przywilej piotrkowski 1388 roku. Szkic historyczno-prawny, [w:] Sredniowiecze polskie i powszechne. Wybór pism, Warszawa 1966, s. 55, pkt 14; Arch. Sang. II, s. 76; Mon. Iur. II, nr 29; CE XV, II, s. 187, nr 149; AKP I, 5. 163, pkt 23; 1II, s. 145, pkt 11; s. 403, pkt 21); "spyszne" (1454, 1496, 1511, 1524, 1564 r. - AKP V, s. 30, pkt 66; IP, s. 284; CIP III, s. 155, pkt 17, w wersji iz 1524 r., pkt 14; VL I, f. 672. Było to terminologia aktów urzędowych: dyplomów królewskich, konstytucji sejmowych. W slowniku lacińsko-polskim Bartłomieja z Bydgoszczy umieszczono termin "zapyszne" $[1532$ r. - Slownik [...] podhug rkpsu z roku 153?, wyd. E. Erzepka, Poznań 1900, s. 90). Zob. też: A. Z a j da, Nazwy staropolskich powinności feudalnych, danin $i$ oplat (do 1600 r.), ZNUJ 1979, Prace językoznawcze, z. 60 . 
Memorctus eciam exactor predictarum eciam pecuniarum pretextu note quod napisne dicitur nichil exigat atque tollat ${ }^{16}$.

Król zakazywal pobierania spiśnego, zapewne dlatego, iż ziemianie nie byli zadowoleni $\mathrm{z}$ istniejącej sytuacji, w której poddani $\mathrm{z}$ ich dóbr placili podatek na rzecz wladcy $\mathrm{i}$ dodatkowo ponosili koszty utrzymania urzędników wybierających podatki. Zasygnalizujmy, iż zmiany w zakresie wynagradzania osób wybierających świadczenia na rzecz panującego zachodzą również na Mazowszu17. W porównaniu z Koroną nastąpiły one nieco później. Statut Bolesława IV, księcia czersko-warszawskiego, z roku 1448 zakazywał poborcom podatków i czynszów książęcych pobierania spiśnego ${ }^{18}$. Z kolei w przywileju z 1462 r. wydanym przez księżnę plocką Katarzynę dla ziemian, postanawiano:

llem exactores censuum nostrorum ducalium a descripcione alias spisne ab hominibus sive kmethanibus terrigenarum peccunias iam de cetereo non exigant, sed de pecunis nostris ducalibus anno quolibet perpetuis temporibus prefati exactores videijcet Plocensis sex sexagenas, Wisznensis tres et Plonensis eciam tres sexagenas grossorum in mediis grossis tollent et levabunt ${ }^{10}$.

Określono tu wyraźnie, że w miejscu spiśnego wyplacana będzie poborcom dorocznego czynszu ${ }^{20}$ określona kwota ze skarbu książęcego.

Jak natomiast ustalona zostala kwestia wynagrodzenia poborców w Koronie? Dla I połowy XV w. posiadamy tylko nieliczne dane źródlowe. Wskazują one na sposób oplacania poborców duchownych wybierających dziesięcinę sześcioletnią, której część przeznaczona byla dla monarchy polskiego ${ }^{21}$. Uchwała kapituly generalnej gnieźnieńskiej z 28.04.1449 r. postanawiała:

Item dnus Administrator cum capitulo pro laboribus, quos fecit dnus Michael altarista domini cantoris exigendo pecunias regales contribucionis, donaverunt sibi IV marcas in mediis grossis ${ }^{22}$.

16 KDWp III (Poznań 1879), nr 1873.

17 O pewnych analogiach $w$ zakresie nakladania podatków zachodzących między Koroną a Mazowszem pisze J. Senkowski, Skarbowość Mazowsza od końca XIV wieku do 1526 roku, Warszawa 1965, s. 176, 179-180, 196, 203, 205 i n.

${ }^{18}$ IMT I, nr 95. Zob. też S e nk ow ski, Skarbowość..., 5. 141.

19 A. Wolff, Studia nad urzędnikami mazowieckimi 1370-1526, Wrocław 1962, s. 306, nr 7; zob. uwage A. Wolffa do tego przywileju, s. 262. Przywilej ten potwierdził 3.05.1463 r. książę plocki Konrad III, JMT I, nr 114.

20 Czynsz książęcy był podatkiem stałym, pobieranym corocznie $\mathbf{w}$ terminie do 11 listopada. Płaciła go ludność zamieszkała we wsiach i miastach prywatnych na Mazowszu: S e nk ow ski, Skarbowość..., s. 106, 124 i n.

21 K a r b ownik, Ciężary..., s. 130.

22 Acta capitularis gnesnensis, posnaniensis et vladislaviensis (1408-1530), vol. I, ed. B. Ula now ski, Kraków 1894, nr 1773. 
W kolejnej uchwale tejże kapituly z 29.04.t.r. stwierdzano między innymi:

Quitancia dno cantori super contribucione [...] Item eciam in distributis pro salario notarii pro cursoribus et papiro posuit VII marcas, I gr inclusis saccis pro pecuniis conservandis ${ }^{23}$.

Z braku innych źródel przytoczmy jeszcze tekst uchwały kapituly krakowskiej z 24.04.1472 r.:

[...] quiquidem dni collectores [...] pro labore suo de pecunis dicte contribucionis debent habere per viginti marcas pecuniarum ${ }^{24}$.

Widzimy w świetle ostatniej uchwały (z 1472 r.), że niewątpliwie poborcy wybierający podatki $w$ dobrach ziemskich kleru wynagradzani byli z zebranych pieniędzy. Dwa wcześniejsze zapisy per analogiam przemawiały za obowiązywaniem tej zasady. Powstaje tu pytanie, czy obowiązywała ona również egzaktorów wybierających świadczenia podatkowe $\mathrm{w}$ dobrach szlacheckich? W nielicznych uniwersalach poborowych z XV w. znajdujemy jedną tylko wzmiankę o wynagrodzeniu poborców. W uchwale podatkowej sejmiku wielkopolskiego w Kole ze stycznia 1458 r. stanowiono:

Item collectores seu exactores sunt deputati in tota terra Poloniae et palatinatu utriusque, videlicet honorabilis dominus Andreas Rogalinski, canonicus cathedralis ecclesiae Poznaniensis, Philippus Sirkowski quorum pro labore suo XX. marcas25.

Nie wiemy, z jakiego źródła miała być wypłacona należna poborcom kwota 20 grzywien. Zarazem na podstawie tej jednostkowej informacji nie sposób stwierdzić, że w XV w. o płacach egzaktorów decydował sejmik.

W Liber qvitantiarum regis Casimiri znajdujemy wpisy, które wskazują na rolę monarchy $w$ tej kwestii. Przytoczmy z nich dwa. Pierwszy pochodzi z 26.08.1485 r.:

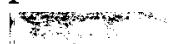

"Eodem die judici predicto cameneczensi dedit Maiestas Regia triginta marcas pecuniarum de exaccione fertonum pro serviciis annorum preteriti et presenti in exigen. dis exaccionibus factis, pro quibus eum nunquam remuneraverat sua Serenitas ${ }^{26}$.

\footnotetext{
${ }^{23}$ Ibidem, $\mathrm{nr} 1776$.

$24 \mathrm{AKH} \mathrm{6,} \mathrm{nr} 163$.

${ }^{25}$ IP, s. 304, pkt XV. Uwagę na to zwrócił W. Małc użyński, Szkice z dziejów skarbowości polskiej, „Ekonomista” 1915; Warszawa 1916, s. 52.

${ }^{25}$ Liber quitantiarum regis Casimiri ab a. 1484 ad 1488 [Księga skarbowa króla Kazimierza Jag.], [w:] Teki Pawińskiego, vol. II, Warszawa 1897, s. 50. O wynagrodzeniụ zob. też $\mathrm{m}$. in. s. 75 zapis $z$ 18.11.t.r., s. 127 ; zapis z 24.01 .1487 r. O zwrocie
} 


\section{Drugi z 19.01.1487 r.:}

[...] data est recognicio nobili Nicolao Sczawyenski exactori gostinensi super viginti marcas pecuniarum, racione diligencie per eum circa exaccionem ipsam facte, de qvibus ipsum Maiestas Regia quitat ${ }^{27}$.

Podobny zapis zamieszczono w księdze skarbowej króla Aleksandra 18.07.1502 r.:

Jacobo de Glinki capitaneo visnensi date sunt viginti quinque marce pecuniarum pro itinere ad Maiestatem Regiam facto, tum pro diligencia, qvam fecit penes exigendis exactionibus recipiendis ${ }^{28}$.

Osoby wybierające podatki nadzwyczajne $z$ dóbr ziemskich (wiardunkowy), jak też wybierające je z miast (szos, czopowe) wynagradzane być mogly przez króla za zebrane przez nich podatki, które odprowadzali do skarbu29. Czy było to wynagrodzenie należne poborcom, czy przejaw łaski królewskiej?

Dalsze wzmianki o opłacaniu poborców pojawiają się w niektórych uniwersalach w czasów Zygmunta I Starego. Wynagrodzenie dla tych urzędników z poszczególnych województw podaje konstytucja Ordinatio contributionum publicarum exigendorum sejmu toruńskiego $\mathrm{z} \quad \mathbf{3 0 . 1 2}$. 1519 r., odnosząca się do wybierania podatków nadzwyczajnych. Ustanawiano w niej wynagrodzenie dodatkowe:

Salarium annuum pro exactoribus designandum et quantum pro expensis unicuique exactori dari debeat ultra mercedem illi designatum: Cracoviensi quinquaginta mar-

kosztów poczynionych przez poborce przy wybieraniu podatków, zob. s. 50; zapis z 18.09.1485 \%. Nie wiemy, czy kwota ścisłle odpowiadała owym kosztom, czy zawierało się w nicj zarazem wynagrodzenie?

27 Ibidem, s. 126.

28 Liber quitantiarum Alexandri regis ab a. 1502 ad 1506 [Ksiega skarbowa króld Aleksandra Jag.], Wanszałwa 1897, s. 23; zob. też s. 4 - zapis z 3.05.t.r. Uwagę na to zwrócil J. Rutkowski, Skarbowość polska za Aleksandra Jagielloriczyka, KH 1909, R. XXIII, s. 76, przyp. 1. O zwrocie kosztów poniesionych przy ściạganiu świadczeń podatkowych zob. zapis z 5.01 .1505 r. Liber quitantiarum Alexandri regis, s. 147 . I w tym wypadku nie wiemy, czy do zwrotu kosztów nie dołą. czono wynagrodzenia.

${ }^{29} \mathrm{Z}$ kolei uniwersał podatkowy sejmiku w Kole z 1489 I., wprowadzając pobór szosu i czopowego $w$ miastach odnośnie do wynagrodzenia poborców szosu, postanawiał item, quod quilibet exactor habeat pro salario annuatim quinquaginta marcas, quibus impensis omnibus oneribus satisfaciat ( $C E X V, I / 2, \mathrm{nr} 256$ ). Nie wiemy, czy wynagrodzenie to pochodziło ze zgromadzonego podatku, i kiedy poborca je odbierał - być może następowało to przy odstawianiu zebranych pieniędzy do skarbu. Inaczej ustalone zostalo wynagrodzenie dla poborców czopowego, które było podatkiem od produkcji et loco expensarum et onerum recipiant pro se septimum quadrantem a vase [ibidem]. 
cae ratione salarii; eidem ratione expensarum quadraginta marcae. Poznaniensi ratione salarii quinquaginta marcae; eidem ratione expensarum quadraginta marcae $[\ldots]^{30}$.

Z kolei w uchwale sejmu krakowskiego z 19.03.1527 r. określono wynagrodzenie dla poborców wybierających podatek, tak w dobrach ziemskich świeckich, jak i kleru:

Exactores in omnibus palatinatibus habebunt pro mercede et expensis suis id, quod in conventu Thorunensi est constitutum, et non plus, videlicet ambo exactores terrae et palatinatus Cracoviensi, spiritualis et saecularis, habebunt pto salario seu mercede annua et expensis XC marcas pecuniarum [... ${ }^{31}$.

Powstaje pytanie, czy poborca duchowny wybierał podatki także w dobrach ziemskich szlachty? Nie podejmując się rozwiązania problemu, wskazać możemy, iż w 1533 r. w ziemi kaliskiej poborca uchwalonych wówczas podatków nadzwyczajnych był kanonik gniénieński Be. nedykt Izdbieński32.

W świetle cytowanych konstytucji podatkowych, opłacanie poborców przybrało charakter rocznego ryczaltu, w tych latach w których uchwalono podatki. Wówczas kwotę wynagrodzenia wyznaczal sejm przy uchwaleniu podatków. System ten funkcjonuje wobec zniesienia oplacania poborców przez podatników, w drodze zakazu pobierania spiśnego. Jednak zniesienie spiśnego w 1388 r. nie było respektowane, o czym świadczo jednoznacznie ponawiane ustawicznie zakazy adresowane do osób wybierających podatki; podejmowano je kolejno w latach: 1425, $1430,1433,1451,1454,1465,1472,1496,1503,1505,1511,1524^{33}$. Wskaż-

30 CIP III, nr 225, pkt 16.

${ }^{31}$ AT IX, nr 72; zob. też IX, nir 74 z t.r.; X, nr 72 z 1528 r.; VL I, f. 551 z 1539 r.; II, f. 741 z 1567 r.; II, f. 1005 i 1036 z 1580 i 1581 r, Por. także uchwała synodu prowincjonalnego łęczyckiego z 1527 r. i synodów piotrkowskiego z 1557 i warszawskiego z 1561 r. w: Materialy do historii ustawodawstwa synodalneqo w Polsice w XVI wieku, zebr. B. Ulanowski, [w:] AKP I(1895), s, 5ij, V pkt 25; s. 128 , art. 5 ; s. 142 , art. 1.

32 AT XV, nr 124, 273. Zっb. tė̇ przyp. 25.

$33 \mathrm{CE} \mathrm{XV}$, II, nr 149 \$ 11; VL I, f. 92; f, 158, 377; IP, s. 267, 284, 312; Correctura statutorum et consizetudinem Regni Poloniae [...], ed. M. B obrzyński, Kraków 1874, s. 101, s. 389; AA, nr 296; Syntagmata, s. 168, pkt 9; CIP III, s. 155, pkt 17 statutów z 1511 r., oraz art. 14 statutów z 1524 r. Uchwałe przeciw pobieraniu spiśnego przez poborców podjęła kapituła płocka 2.02.1503 r. AKH 6, nr 522. Odmiennego zdania jest $K$ arbownik, przyjmując, że zakazy pobierania spiśnego w XV w. były przestrzegane tak w posiadłościach szlacheckich, jak duchowieństwa diecezjalnego, i w stosunku do większości dóbr klasztornych. (Ciężary..., s. 58-59). Autor nie wskazał źródeł. Być może za podstawę do wniosku posłużyły postanowienia o zakazie pobierania spiśnego z lat 1430, 1447 (winno być 1451, zob. VL I, f. 158), 1496 i 1511, powołane w zdaniu woześniejszym. 
my, że analogiczny zakaz napotykamy w dokumencie Wladyslawa Jagielly wystawionym dla osób prywatnych. Mianowicie w przywileju z 30.04.1410 r. nadanym dla panów z Dębna umieszczono passus odnoszący się do wolności podatkowej. I tu zakazywano pobierania spiśnego przy ściąganiu poradlnego ${ }^{34}$. Wymienione wcześniej zakazy pobierania tej opłaty odnosiły się do poborców wybierających zarówno podatki zwyczajne, jak i nadzwyczajne ${ }^{35}$. A zatem w praktyce wynagrodzenie egzaktorów w XV w. składało się z dwóch części: z oficjalnej, pochodzącej z zebranego podatku (ryczalt), i drugiej pobieranej nadal wbrew prawu w postaci spiśnego ${ }^{36}$.

Zakaz pobierania tej nieoficjalnej części wynagrodzenia, jakim było spiśne, znika w ciągu XVI w. Uniwersal podatkowy z 1564 r., odnoszący się do podatku podwodowego, zezwalal pisarzowi starościńskiemu na pobieranie spiśnego przy okazji skladania przez miasta i wsie tego podatku ${ }^{37}$. Nie dysponujemy źródłami, które pozwalałyby stwierdzić wprost, czy zezwolenie pobierania spiśnego dotyczy także innych podatków. Pośrednie dane zóają się wskazywać, że mogło ono być wybierane ${ }^{38}$.

Istotniejsze jednak zmiany w zalkresie wynagrodzenia poborców mają miejsce na przelomie XVI/XVII w. W uniwersale z 1591 r. postanawiano:

Salaria Poborcom y szafarzom takie n znaczamy, że od każdego złotego z iego Woiewodztwa, który z poborów wszelakich y czopowego przyidzie, by też y czopowe

$3 \pm$ Mon. Iur. II.

$35 \mathrm{~T}$. Szulc, Organizacja poboru podstków pokoszyckich do polowy XVI wieku, CPH 1988,40, z. 3 , s. $68-69,76$.

36 Argumentem przemawiającym za traktowaniem spiśnego nadal jako wynagrodzenie poborców było zatytułowanie uchwały wymierzonej przeciw pobieraniu spiśnego De salaris ab exaccionibus non exigendis, AKP 5, s. 30(66). Z kolei w słowniku łacińsko-polskim Bartłomieja z Bydgoszczy z 1532 r. napotykamy na podobne ujęcie terminu spisnego "Salarium, zapłata, nyto, praemium pro mercede laboris etc., dictum quasi solarium zapyszne", Slownik $[.$.$\rfloor podlug rkps z roku 1532$, wyd. B. Erzepk a, Poznaí 1900, s. 90.

37 VL II, f. 672.

\&8 W związku z przeprowadzeniem w 1557 r. na Litwie pomiary włócznej, dozwolono tam pobierać spiśne od włóki, zob. Obraz Litwy pod względem jej cywilizacji od czasow najdawniejszych do końca wieku XVIII przez J. Jaroszewicza [...]. Wilno 1844 , s. 257, art. XXXI - nie wiemy jednak, czy w tym przypadku spiśne zwiazane było z wybieraniem podatkówi Lustracje wojew. podlaskiego 1570 i 1576 roku, wyd. J. Topolski, J. Wiśniewski, Wrocław 1959, s. 4, 8, 72. Pobierali ją poborcy od wlóki; zob. też Księgi referendarskie, vol. I, $1582-1602$, wyd. I. T. B a r a n o wski, Warszawa 1910, s. 16: "Spisnego z włoki jednej od wszystkich podatkow jedno 1,5 pols. wydawać mają temu, kto to wybierác będzie"; Dekret Zygmunta III pomiędzy [...] starostq suraskim a poddanymi suraskimi, z 1592. r. 
arendowane było, Poborca ieden szeląg [...] względem salaria y nakładow, brac maiąas.

Przypuszczalnie dotychczasowy sposób oplacania, polegający na wyznaczeniu z góry wynagrodzenia dla poborców, nie był efektywny, nie uzależnial on plac egzaktorów od wyników ich dzialalności. Ten mankament mial usunąc nowy sposób opłacania, czyniąc poborców bezpośrednio zainteresowanymi rezultatami ich pracy. Wynagrodzenie w tym wypadku byloby formą prowizji, gdyż jej wysokosć zależała od sumy podatku, którą zebral i wplacil do skarbu. Nie jest to jedyna nowość. Uporczywa praktyka pobierania wbrew prawu spiśnego spowodowala, iż zostaje ona ostatecznie uznana przez państwo szlacheckie. W $1618 \mathrm{r}$. uniwersal poborowy sejmu warszawskiego zezwalal puborcom i ich subkolektorom, obok salarium $w$ postaci prowizji od zebranego podatku, pobierać kwitowe w wysokości nie większej niz 2 gr przy wystawieniu poświadczenia o zaplaceniu podatku ${ }^{40}$. Koszty utrzymania aparatu poborców rozłożone zostały na państwo i podatników ${ }^{i 1}$.

Nasuwa się tu pytanie, czy istotnie spiśne i kwitowe można z sobą utożsamiać, czy też oznaczaja dwie różne instytucje? Aby rozstrzygnąí wątpliwości, porównajmy teksty źródłowe, w których występują powyższe terminy. Oto przykładowe dwa teksty z XV w. odnoszące się do spiśnego.

Memoratus etiam exactor pecuniarum praedictarum praetextu note (quod napisne dicitur) nihil exigat, atqve tollat et nihilominus litteris suis kmethones quittet de solut is ${ }^{42}$,

Volumus etiam, quod notarii, tam nostras regales contributiones, quam etiam capitaneorum exigentes pecunias, ratione notae, alias spyszne, tam spiritualium, quaill saecularium, nullatenus recipiant $[\ldots]^{43}$.

Zabraniano poborcom przy wystawianiu kwitów podatkowych pobierania spiśnego.

Z kolei źródła odnoszące się do XVII-wiecznego kwitowego brzmią:

\&9 VL III, f. 1394; z kolei w konstytucji z 1593 r. postanowiono: „Salaria tym poborcom maią bydź rachowane, od każdego złotego po groszu iednemu: $z$ którego salurium iuż y koszt odwożenił pieniędzy do skarbu odprawować máaq", VL II, f. 1423; podobnie: f. 1575 z 1602 r.; f. 1593 z 1603 r.; f. 1658 z 1607 r.; f. 1694 z 1609 r.; III, f. 66 z 1611 r. Wskażmy, że za panowania Zygmunta 111 I zł dzielil się m. in. na $30 \mathrm{gr}$, co stanowiło 90 szelągów, tym samym 1 szeląg równał się $1 / 3 \mathrm{gr}$; zob. J. Szymański, Nauki pomocnicze historii, Warszawa 1983, s. 600.

40 VL III, f. 343; analogiczne ujęcie $w$ konstytucji Salarium poborcom $W W$. X. Litew. z 1616 r., VL III, f. 318.

41 Uwage na to zwrócil A. Paw ins $\mathrm{xi}$, Rzqdy sejmikowe w epoce królów ele. kcyjnych 1572-1795, t. 1, Warszawa 1888, s. 170-171.

$42 \mathrm{VL}$ I, f. 92 z $1430-1433$ I.

43 IP, s. 267 z $1454 \mathrm{r}$. 
[...] áby od kwitów nie więcej jedno po groszu jednemu pp. poborcy brali sub poenati

[...] aby kwitowe, które przy podatkach RP. zwykli sobie [...] poborcy pretencuwać, odcięie albo przynajmniej moderowane bylo ${ }^{45}$;

Do klulych wybierania podymnego IMć p. poburca kwitowego nie ma więcej nad groszy sześć ze wsi zupełnej ani nic od regestr, jeśliby kto kwitu nie miał nic wy$\operatorname{cic}_{i} g a c^{46}$.

Zatem egzektorzy za wystawienie kwitu dokumentującego uregulowanie swiadczenia podatkowego otrzymywali zaplatę, zwaną w tym przypadku juz nie spiśną, lecz kwitową. Spiśne i kwitowe to terminy pleonazmy.

Sejmiki, których rola znacznie wzrasta w XVII w., poświęcają od lat czterdziestych tego stulecia coraz więcej uwagi zagadnieniu ustalania wynagrodzenia poborców. Obserwujemy to w laudach sejmikowych. Mowa w nich o trzech sposobach oplacania egzektorów. Pierwszy, który przeważal - polegal na przerzuceniu ciężaru utrzymania na podatnika, na drodze obciązenia go opkatą kwitową47. Równolegle występował drugi, sprowadzający się do ustalenia prowizyjnego salarium ${ }^{48}$. Trzeci kączył w sobie dwa poprzednie, zezwalając poborcom na pobranie i salarium i kwitowego, jeánakże występował on sporadycznie ${ }^{\mathbf{4 9}}$.

Od początku XVIII w. wydaje się brać górę tendencja do oparcia oplacania poborców na wyznaczonym przez sejmik salarium z równoczesnym zakazem wybierania kwitowego ${ }^{\tilde{0}}$.

4: ACiZ XX, nr 114, pkt 38 z 2.01.1618 r.

45 Akta krak. II, nr 102, pkt 4 z 7.01.1642 r.

4: AGZ XXIV, ni 70, pkt 7 z 23.07.1653 r

47 Przejrzeliśmy: AGZ XIX-XXV; Akta krak. II-IV; Lauda II-V; AH X. Powyższa podstawa źródiowa odnosi się równieź do przyp. 47-49. Dla okresu 1618-1716 r. stwierdziliśmy 34 tukie przypadki, np.: AGZ XXI, nr 35, pkt 3 z 10.02 . 1650 r.i nI 126, pkt $2 \mathrm{z} 20.03 .1657$ r. Do tej grupy zaliczyliśmy zapiski, z których wynika, iz jako salarium poborcy otrzymuja kwitowe. Uchwal takich w latach 1643-1695 bylo 9; przykładowo zob. AGZ XXI, nr 72, pkt 15 z 11.08.1654 r.; Akta krak. IlI, nr 16 z 18.08.1661 r.; Lauda III, nr 37 z 11.07.1695 r.

48 Dla lat 1652-1711 znaleźliśmy 30 uchwał sejmikowych; zob. np.: AGZ XXI, or 117 pkt 20 z 19.01 .1657 r.; XXII, nr 1, pkt 11 z 29.12 .1673 r.i Akta krak. IV, nr $4 \mathrm{z} 12.04 .1674 \mathrm{r}$. Wskażmy, że mimo sporadycznych informacji o kwitowym w laudach kujawskich, zamieszczenie w treści przysięgi skladanej przez poborców sformulowania "solariis ichm. pp. poborcow solitis od kwitu po szostaku od zlotego grosz salvis inanentibus", Lauda II, nr 73 z 1670 r., oznacza zwyczajowe wybieranie kwitowego w ziemi kujawskiej w XVII w.

${ }_{49} \mathrm{~W}$ okresie $1643-1710 \mathrm{r}$. bylo tych uchwał 11; zob. m. in.: AGZ XX, nr 218, pkt 3 z 12.05 .1643 r.i XXI, nr 72, pkt 15 z 11.08.1654 r.i Lauda II, nr 27 z 31.10. $1658 \mathrm{r}$.

${ }^{50}$ Dla lat 1712-1767 naliczyliśmy 15 tego typu uchwał sejmikowych; przykłado- 
W okresie stanisławowskim wprowadzono dla poborców pensje. Komisja Skarbowa w 1776 r. określiła, że za każdą ratę podatku otrzymują oni 750 zł, a w 1789 r., w związku z wprowadzeniem nowych podatków - pensje poborców podwyższono do $2200 z^{51}$.

\section{III}

Spiśne $\mathrm{w}$ Koronie pobierane było od jednostki osadniczej - wsi ${ }^{52}$. Wynika to $z$ przywilejów wydanych przez Ludwika Węgierskiego dla instytutów duchownych w 1381 r. Wskazywano w nich:

[...] decernimus pretextu recolligendo pecunie nullus notariorum seu eciam ministerialium quitquid [sic] exigat seu requirat nisi unum grossum de qvalibet villa ${ }^{53}$.

Wybieranie spiśnego od wsi ${ }^{54}$ potwierdzają przepisy o egzekucji prowadzonej $\mathrm{w}$ stosunku do zalegających $\mathrm{w}$ placeniu poradlnego podatników. W razie niezaplacenia podatku przez wieś $\mathrm{w}$ terminie, była ona pociągana do odpowiedzialności ${ }^{55}$. Inaczej bylo na Mazowszu, gdzie spiśne wybierano od poszczególnych chlopów, nie zaś od wsið̄

Źródla XV-wieczne odnoszące się do Korony - w przeciwieństwie do przywileju z 1381 r. - nie wskazują podstawy, od której otrzymywano spiśne ${ }^{\overline{5}}$. Jak się wydaje, bylo to zbędne, z uwagi na obowiązują-

wo zob.: AGZ XXV, nr 139, pkt 7 z 12.09 .1714 r.; $\mathrm{nr} 178$, pkt 8 z 16.09.1721 r.; nr 342, pkt 5 z 15.09 .1767 r. Drukowane wydawnictwa uchwał sejmikowych, odnoszące slię do XVIII w, są nieliczne, w związku z tym (nie sięgając do rękopisów) nie wiemy, czy informacje zawarte $w$ laudach ruskich nie wyrażają tylko tendencji lokalnej. Nie wiemy też, $w$ jakim stopniu te ograniczenia odnośnie do pobierania kwitowego były przestrzegane.

51 T. Korzon, Wewnętrzne dzieje Polski za Stanislawa Augusta (1764-1794), vol. III, Warszawa 1897 , s. 124.

52 $\mathrm{M}$ atuszewski, Immunitet..., s. 130-131, za nim idą: $\mathrm{Zgór} \mathrm{njak,} \mathrm{Relikty...,}$ s. 67; Brzeczkowski, Podatki..., s. 42. Podobnie przyjmuje Karbownik, Ciężary..., s. 59 .

53 CDP 3, nr 164.

54 Wieś naleźy rozumieć zarazem jako jednostkę własnościową. Pan feudalny w niektórych przypadkach był pośrednikiem $w$ przekazywaniu podatków między chłopem a egzaktorem; zob. Szulc, Organizacja..., s. 71, 72-74. Wystarczyło wówczas wystawienie tylko jednego kwitu dla wsi.

${ }_{65}$ KDWp 3, nr 1873.

s6 Senk owski, Skarbowość..., s. 141-142; IP, s. 456; IMT 1, s. $168 \mathrm{nr} 95$, s. 170 .

${ }^{67}$ Zob. przyp. 32 . 
ce wówczas zakazy jego pobierania. Nieliczne dane źródłowe z XVI w. pozwalają przyjąć wniosek, że nadal wybierano spiśne od wsi, jak i miast, naturalnie przy okazji wystawienia kwitu podatkowego ${ }^{58}$. Podobnie było w XVII i w początkach XVIII w., jak wynika to z ówczesnych laudów sejmikowychis. Ale od tej zasady znajdujemy odstępstwa, bowiem w XVII w. pojawiają się w uchwałach sejmikowych informacje pozwalające stwierdzić, że sporadycznie podstawa wybierania kwitowego była inna. W kilku uchwałach sejmiku księstw zatorskiego i oświęcimskiego $w$ Zatorze, podjętych $w$ latach 1658-1671, natrafiamy na postanowienia o wyznaczeniu dla poborcy ,,kwitowego od kaźdego złotego grosz jeden"60. Niewykluczone, że na pojawienie się takiej pudstawy kwitowego mialo wpływ wynagrodzenie (salarium) prowizyjne, pobierane $w$ takirn samym stosunku od schylku XVI w. W tej formie kwitowego znalazła zarazem wyraz tendencja przejawiająca się $w$ dązeniu podatników do zrzucenia z siebie cięzaru utrzymania poborców i wprowadzenia $w$ tym zakresie zasady partycypacji ekzaktorów $w$ wybieranych przez nich podatkach. W takim razie - jak można przypuszczać - wysokość kwitowego uzależniona była od sumy zebranego podatku, od solidności wybierającego, od niepozostawiania przez niego retent. W laudach napotykamy jeszcze dwie informacje, z których każda wymienia inną podstawę pobierania kwitoweg. Sejmik relacyjny księstw zatorskiego i oświęcimskiego w Zatorze z 12.07 .1655 r. wyznaczyl poborcy kwitowe „od każdego lanu"bi, zaś sejmik ziemski halicki z 1.08.1707 r. ustanowil ,kwitowe po tyntowi od każdego dymu"62. Być może tą drogą, chciano - z uwagi na niską stawkę kwitowego - urealnić jej wartość. W ten sposób liczone kwitowe -- jak się wydaje - dawalo poborcom większe korzysci materialne, anizeli to pobierane od $\mathrm{wsi}^{63}$.

¿ VL 1I, t. 6i2; zob. też Lustrucja województwa krakowskiego 1564 r., cz. I, wyd. J. Malecki, Warszawa 1962, s. 167. Nie wiemy, kto otrzymywal ów kwit: soltys, pan dominialny, wies(?).

59 AGZ XXI, nr 2, pkt 1; nr 39, pkt 7; nr 70, pkt 7; nr 72, pkt 15; nr 163, pkt 2; XXII, nr 172, pkt 10; XXIII, nr 56, pkt ji XXIV, nr 204, pkt 4; nr 224, pkt 5; nr 225, pkt 5; nr 233, pkt 5; XXV, nr 3, pkt 6; nr 19, pkt 16; nr 55, pkt 7; Lauda IV, nr 154.

ou AGZ XXV, nr 202, pkt 4; Akta krak. II, nr 236; Ill, nr 16, 18, 72, 77, 153.

"Akta krak. II, nr 199, s. 542.

:2 AGZ XXV, nr 58, pkt 5 .

${ }^{63} \mathrm{~W}$ uchwale sejmiku halickiego z 9.01 .1702 r. postanowiono: „A że szczupłe kwitowe przy tak wielkich pracach le aźniejszych iMc pp. egzaktorów, żeby od juramentów nie trudnili soluta, $\mathrm{z}$ tejże suny wybrunia rogowego in vin meritorum każdego z IMciów po tysiącu zł. naznaczyliśmy, które IMć z wybranej sumy odebrać sobie maią", AGZ XXV, nr 27, pkt 8. 
Byloby dziwne, gdyby przez tyle stuleci funkcjonowal w Polsce jednolity sposób wynagradzania urzędników podatkowych. W sferze prawa stanowionego obserwujemy ewolucje w zakresie oplacania poborców. Począwszy od systemu polegającego na utrzymywaniu aparatu podatlowego $z$ robocizn i dochodów $w$ naiurze pochodzących z lanów chlopskich i folwarków oraz z wpływów z młynów, kar, dziesięciny drzewnej (czasy Kazimierza Wielkiego), poprzez opłacanie ich przez podatników (czasy Ludwika Węgierskiego), następnie przez partycypację egzaktorów $\mathrm{w}$ zebranych podatkach w postaci ryczaltu (XV - I. połowa XVI w.) aż po system noszący znamiona prowizji od zebranego podatku (od końca XV w.). W XVII w. obok prowizyjnego salarium dopuszezono drugi składnik w postaci kwitowego. Wcześniejsza postać kwitowego, spiśne (od wsi), mimo zakazów, było pobierane bezprawnie od podatników przez osoby egzekwujące podatki (XV - I. polowa XVI w.). Zatem, w tym czasie wynagrodzenie składało się $z$ części oficjalnej i nieoficjalnej. W okresie rządów sejmikowych $\mathrm{w}$ praktyce występowal niejednolity sposób wynagradzania, mianowicie: albo kwitowe, albo prowizja, albo jedno i drugie razem. Podkreślmy, że zasada partycypacji poborców w wybieranych podatkach utrzymuje się niemal przez cały okres istrie. nia Rzeczypospolitej, by w II. polowie XVIII w. ustąpić pensji ze skarbu państwa. 